\title{
Effect of the Water Extracts of Avocado Fruit and Cherimoya Leaf on Four Human Cancer Cell Lines and Vicia Faba Root Tip Cells
}

\author{
Noha S. Khalifa ${ }^{1}$, Hoda S. Barakat ${ }^{1}$, Salwa Elhallouty ${ }^{2} \&$ Dina Salem ${ }^{1}$ \\ ${ }^{1}$ Department of Botany, Faculty of Science, Ain Shams University, Cairo, Egypt \\ ${ }^{2}$ National Research Center, Department of medicinal drugs, Giza, Egypt \\ Coresspondance: Noha S. Khalifa, Department of Botany, Faculty of Science, Ain Shams University, Cairo, Egypt. \\ Tel: 20-106-418-2978. E-mail: Nohakhalifa@hotmail.com
}

\author{
Received: July 18, 2012 Accepted: March 3, 2013 Online Published: June 15, 2013 \\ doi:10.5539/jas.v5n7p245 URL: http://dx.doi.org/10.5539/jas.v5n7p245
}

\begin{abstract}
The main objective of this study is to determine the effect of the water extract of Persea americana Mill. (avocado fruit) and Annona cherimolia Mill (cherimoya leaf) on living cells. The antiproliferative properties of avocado fruit water extract (AFWE) and cherimoya leaf water extract (CLWE) were determined using four human cancer cell lines: lung (A549), liver (HepG-2), colon (HT-29) and breast (MCF-7). Cancer cells were incubated with 100 $\mu \mathrm{g} / \mathrm{ml}$ of AFWE or CLWE for 48 hours, then the cell viability was measured using colorimetric tetrazolium cleavage test (MTT). Both extracts resulted in more than $90 \%$ mortality in treated cells. Vicia faba root tip assay was used to determine the effect of AFWE and CLWE on mitotic index (MI), Micronuclei (MN) formation rate and chromosomal abnormalities. Vicia faba roots were soaked in 100, 1250, 2500, 5000, 10000, $20000 \mu \mathrm{g} / \mathrm{ml}$ of AFWE or ALWE for 4 and $24 \mathrm{~h}$. AFWE and CLWE were mitodepressive and resulted in a significant decrease of MI in a dose dependant manner. CLWE treatment resulted in a decrease in prophase cell percentage and an increase in MN \& chromosomal abnormalities. On contrary, the prophase cell percentage was linearly increasing with the applied concentration without micronuclei formation in avocado treatment. Our results strongly indicate that avocado and cherimoya extracts were highly cytotoxic and mitodepressive on cancer and plant cells, respectively.
\end{abstract}

Keywords: Annona cherimolia, Persea americana, micronuclei, mitotic index, Vicia faba root assay

\section{Introduction}

The diverse plant kingdom is gaining global recognition as unique and renewable resource for the discovery of phytochemicals that may represent pharmacological active compounds (Am, Al-Malki, Refai, Kumosani, \& Moselhy, 2013). Phytochemicals are used in many aspects such as food supplements (Abrahim, Kanthimathi, \& Abdul-Aziz, 2012; Adebajo et al., 2012), immunity enhancers (Bayrami \& Boskabady, 2013; Benmebarek, Zerizer, Laggoune, \& Kabouche, 2013; Buapool et al., 2013), wound healers (Chandra, Yadav, Mani, Ghosh, \& Sachan, 2013), cancer preventive and therapeutic agents (Bhagat, Sharma, \& Saxena, 2012). Cancer prevention through the diet can be considered as an effective tool to improve public health and reduce the cost for healthcare (Haniadka, Popouri, Palatty, Arora, \& Baliga, 2013). According to Newman et al. (2007), 40\% of all anticancer drugs are developed from natural products while $20 \%$ are synthetic derived from natural ones. However, the detection of an active compound with a biological activity of interest in about 250000-500000 unexplored plant species is similar to find a needle in a haystack (Rates, 2001).

The study of natural bioactive compounds in plants has required the development of bioassay techniques. It is not always possible to test against cancer in animal models due to the system complexity. In vitro methods allow the screening of large numbers for cytotoxicity against many types of cancer cell lines and usually require less test material, time and money (El-Menshawi et al., 2010).

Plant bioassays that measure mitotic cell cycle, micronuclei induction rate and the frequency of chromosomal aberrations are both time and cost effective. These tests are helpful in screening the bioactivity of plant extracts at large scale, particularly in areas with limited funds. They will also eliminate the hazards of using cultured human cells and experimental animals. Plant bioassays are mainly used in most ongoing research to determine the genotoxic effect of chemical compounds rather than testing their pharmaceutical properties. 
Root tip meristems of Vicia faba (broad beans) have been used as a pioneer cytogenetic material for the detection of genotoxicity in many studies (Dong \& Zhang, 2010; Ma, Cabrera, \& Owens, 2005). This bioassay was validated by the International Programme on Chemical Safety (IPCS, WHO) and the United Nations Environment Program (UNEP). As far as the authors are aware, Vicia faba root tip assay had not been used for screening natural plant extracts for their anticancer potential.

Persea americana Mill. (avocado) is an economically important tropical tree belonging to family Lauracea. From phytochemical perspective, extracts of the plant yield functionalized alkanols known as aliphatic acetogenins (Kawagishi et al., 2001). Avocado is used in treating tumor in ethnomedicine and exhibits a chemoprotective effect on human cells (Paul, Kulkarni, \& Ganesh, 2011).

Annona cherimolia Mill. (Cherimoya) is a subtropical tree that belongs to family Annonaceae. Cherimoya showed a significant cytotoxic potential in pancreatic, mammary, prostatic, and kidney cancer cells (Alali, Liu, \& McLaughlin, 1999). Members of this family gained more interest due to the presence of the secondary metabolite acetogenins. Acetogenins can be used as antiparasitic, antimicrobial, antimicotic, immunosuppressive, cytotoxic and antitumorous agents (Garcia-Aguirre, Zepeda- Vallejo, Gallegos, Alv arez-Gonzalez, \& Madrigal-Bujaidar, 2008).

Avocado and cherimoya are known to posses stronger cytotoxic effect in tumorous than in normal cells. Some studies showed that plant and animal cells exhibited similar responses towards treatments with bioactive compounds (Konuk, Liman, \& CİĞERCİ, 2007). To determine of this is the case, we tested the cytotoxic effect of avocado fruit water extract (AFWE) and cherimoya leaf water extract (CLWE) on four human cancer cells and meristematic plant cells. The bioactivity of the water extracts of avocado and cherimoya had never been tested on human cancer cell lines or plant cells else where. Therefore, this study will be very helpful in highlighting the activities of both extracts and also to compare between the efficiency of the two bioassays in determining their bioactivity. For this aim, the anticancer properties of ALWE and CLWE were determined using four human cancer cell lines: A549 (human lung carcinoma), HePG2 (human liver carcinoma), HT29 (human colon carcinoma) and MCF-7 (human breast carcinoma). The genotoxic effects of the two extracts were determined by measuring the mitotic index (MI), micronuclei (MN) formation rate and chromosomal abnormalities in Vicia faba root tip cells.

\section{Materials and Methods}

\subsection{Plant Materials}

Fresh samples of Persea americana fruit and Annona cherimoli leaves were obtained from El Orman Botanical Garden (Giza, Egypt). The plants were identified by the herbarium officer of El Orman Garden: Mrs Teriz Labib. Voucher specimens were kept in the herbarium, Botany Department, Faculty of Science, Ain Shams University, under the name of Noha-Dina (2009). Leaves were collected at approximately similar age (the third fully expanded leaves from the top of each branch) and fully ripened dry fruits of P. americana were used. Seeds of Vicia faba (cultivar: Windsor white) were kindly provided by the Agriculture Research Centre, Ministry of Agriculture, Giza, Egypt and was used as a reference model in the root tip bioassay.

\subsection{Preparation of Extracts}

Water extracts were prepared by dissolving 2 grams of fresh material in $100 \mathrm{ml}$ of $90^{\circ} \mathrm{C}$ distilled water, incubated at the same temperature for $15 \mathrm{~min}$, cooled, filtered and used as a stock $(2000000 \mu \mathrm{g} / \mathrm{ml})$. Water extracts were prepared and used the same day of collection to avoid any change in its activity.

\subsection{Cell Culture}

A549 (human lung carcinoma), HePG2 (human liver carcinoma), HT29 (human colon carcinoma) and MCF-7 (human breast carcinoma) were obtained from Karolinska Institutet, Stockholm, Sweden. All cells were maintained in RPMI 1640 (Lonza Biowahittkar) medium except for MCF-7 cells which were maintained in DMEM medium (Lonza Biowahittkar). All the media were supplemented with $1 \%$ antibiotic-antimycotic mixture (10.000 U/ml Potassium Penicillin, $10.000 \mu \mathrm{g} / \mathrm{ml}$ Streptomycin Sulfate and $25 \mu \mathrm{g} / \mathrm{ml}$ Amphotericin B and 1\% L-glutamine. All antibiotics and L- glutamine were purchased from Biowest, France.

\subsection{MTT Viability Assay}

The viability of cancer cell lines was determined after the exposure to water extracts for $48 \mathrm{~h}$ using MTT [3-(4,5-dimethylthiazol-2-yl)-2,5-diphenyltetrazolium bromide] assay as described in Mosmann (1983).

\subsection{Root Tip Preparations and Treatment}

Vicia faba dry seeds were rinsed and then soaked in distilled water for $24 \mathrm{~h}$. Germinating seedlings were kept at $25^{\circ} \mathrm{C}$ on moist gauze until their primary roots were $1-2 \mathrm{~cm}$ in length (Cotelle, Masfaraud, \& Férard, 1999). Root 
tips were soaked for 4 or $24 \mathrm{~h}$ in different concentrations of water extracts $(100,1250,2500,5000,10000,20000$ $\mu \mathrm{g} / \mathrm{ml})$. Distilled water was used as negative control. All treatments were done in triplicates at temperature of $25 \pm 2^{\circ} \mathrm{C}$

\subsection{Cytological Study and Slide Preparation}

Root-tips were cut directly into Carnoy's solution [absolute alcohol: glacial acetic acid (3:1)] and incubated at room temperature for $24 \mathrm{~h}$. Roots are then hydrolyzed in $1 \mathrm{~N}$ analar $\mathrm{HCl}$ at $58-60^{\circ} \mathrm{C}$ for $10 \mathrm{~min}$ (Qian, 2004). Root tips- $3 \mathrm{~mm}$ long- were squashed and stained according to Darlington and La-Cour (1976) Leuco-basic Fuchsin technique. Light green dye $(0.3 \%)$ was used for background staining of the cytoplasm. Root tips were squashed in $45 \%$ acetic acid. Dehydration was done using ascending series of ethyl alcohols; $30 \%, 50 \%, 70 \%, 96 \%$, absolute alcohol; absolute alcohol: xylene (1:1) and xylene, keeping root tips for $5 \mathrm{~min}$ in each concentration. Preparations were mounted in Canada balsam and placed at $45^{\circ} \mathrm{C}$ in the oven (until completely dry). Root tips were examined for micronuclei frequencies and other abnormalities at 4000x magnification using Leica light microscope. The photomicrographs were taken from the prepared slides using digital camera (Sony, $8 \mathrm{Mp}$ ).

2.7 Mitotic Indices (MI) were Calculated Using the Following Formula:

$$
\text { Mitotic index }(\mathrm{MI})=\frac{\text { Number of dividing cells } \times 100}{\text { Total cells examined }}
$$

\subsection{Statistical Analysis}

Data shown are the means and standard errors of three or more independent experiments. Statistical comparisons between groups were made by Student's t-test using Microsoft excel program, and a P-value $<0.05$ considered to be statistically significant.

\section{Results}

\subsection{Cytotoxic Effect of Plant Extracts on Cancer Cell Lines}

Avocado fruit water extract (AFWE) exhibited strong cytotoxic effect against all cancer cell lines used in this study (Table 1). The extract resulted in lethal percentages of $93.3 \%, 98.3 \%, 97.8 \%$ and $91.7 \%$ in A-549 HepG-2 HT-29 and MCF-7 human cancer cell lines, respectively. The cytotoxic effect of avocado extract was more pronounced as compared to that of cherimoya leaf water extract (CLWE) in HepG-2 and HT-29 cancer cell lines. The cytotoxic concentrations of the two extracts were also tested over a range of dilutions on the four cancer cell lines to determine their $\mathrm{LC}_{50}$ (Table 2 and Figure 1). Both $P$. americana and A. cherimolia water extracts showed $\mathrm{LC}_{50}$ value less than $30 \mu \mathrm{g} / \mathrm{ml}$ in HepG-2 cell lines with $\mathrm{LC}_{50}=13.3 \& 10 \mu \mathrm{g} / \mathrm{ml}$ and $\mathrm{HT}-29$ cell line with $\mathrm{LC}_{50}=$ $13.3 \& 16 \mu \mathrm{g} / \mathrm{ml}$, respectively.

Table 1. In vitro cytotoxic activity of crude methanolic extracts tested against human carcinoma cell lines (A549, HepG-2, HT-29 \& MCF-7) after 24 hours

\begin{tabular}{lllll}
\hline Plant name & Mean A-549 & Mean HepG-2 & Mean HT-29 & Mean MCF-7 \\
\hline Persea americana fruit & 93.3 & 98.3 & 97.8 & 91.7 \\
+ve control (Annona Cherimolia) & 95 & 94 & 93 & 94 \\
DMSO & 0 & 0 & 0 & 0 \\
-Ve control & 0 & 0 & 0 & 0 \\
Blank & - & - & - & - \\
\hline
\end{tabular}

Table 2. $\mathrm{LC}_{50}$ values related to MTT assay of the water extract of avocado fruit and cherimoya leaf on human cancer cell lines. Values are in $\mu \mathrm{g} / \mathrm{ml}$

\begin{tabular}{lll}
\hline \multirow{2}{*}{ Cell line } & Lethal concentration $\left(\mathrm{LC}_{50}\right)$ & \\
\cline { 2 - 3 } & Avocado fruit water extract (AFWE) & Cherimoya Leaf Water extract (ALWE) \\
\hline A-549 & 35.4 & 9.8 \\
HepG-2 & 13.3 & 10 \\
HT-29 & 22 & 9.7 \\
MCF-7 & 54.5 & 6.5 \\
\hline
\end{tabular}


LC50 values of avocado and cherim oya on the cancer cell lines used in this study

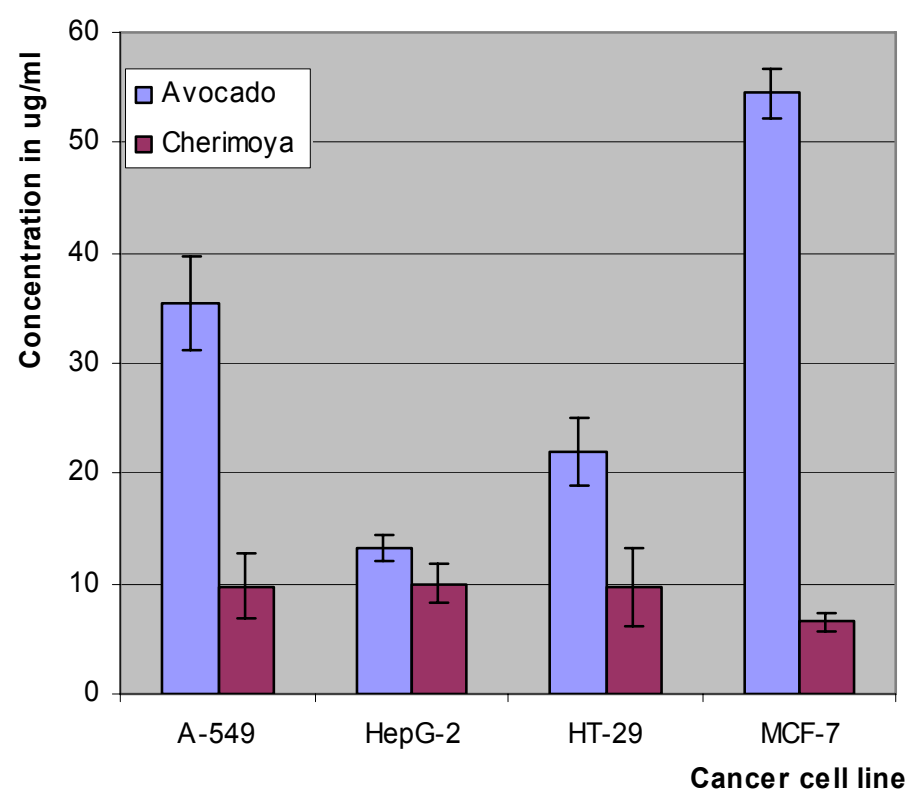

Figure 1. $\mathrm{LC}_{50}$ of the water extract of Persea americana fruit and Annona cherimolia leaves in relation to the four cancer cells lines

\subsection{The Effect of Plant Extracts on Mitotic Indices}

As shown in Table (3), we observed a decrease in the mitotic indices of root tip cells of Vicia faba in a dose-dependant manner in all plant extracts used. Differences in mitotic indices between the treated plants and the untreated control were significant at the highest concentrations of 10000 and $20000 \mathrm{ppm}$, applied for $4 \mathrm{~h}$, for all treatments applied. In $24 \mathrm{~h}$ treatments, the mitotic indices were significantly reduced as compared with control at concentrations of 5000, 10000 and $20000 \mathrm{ppm}$.

Table 3. The effect of plant extracts on the mitotic index of Vicia faba $\mathrm{L}$.

\begin{tabular}{|c|c|c|c|c|c|}
\hline & \multirow{2}{*}{$\begin{array}{l}\text { Plant extract } \\
\text { Conc. } \mu \mathrm{g} / \mathrm{ml}\end{array}$} & \multicolumn{2}{|l|}{ Persea americana } & \multicolumn{2}{|l|}{ Annona cherimolia } \\
\hline & & Number of cells observed & $\mathrm{MI}(\mathrm{X} \pm \mathrm{SE})$ & Number of cells observed & $\mathrm{MI}(\mathrm{X} \pm \mathrm{SE})$ \\
\hline \multirow{7}{*}{4 hours } & Control & & & & \\
\hline & 100 & 3360 & $2.98 \pm 0.57$ & 3078 & $3.44 \pm 0.55$ \\
\hline & 1250 & 4200 & $2.86 \pm 0.39$ & 3850 & $3.17 \pm 0.43$ \\
\hline & 2500 & 4117 & $2.77 \pm 0.49$ & 4077 & $2.87 \pm 0.38$ \\
\hline & 5000 & 3640 & $1.92 \pm 0.68$ & 4428 & $2.14 \pm 0.55$ \\
\hline & 10000 & 4200 & $1.50 \pm 0.61^{*}$ & 3630 & $1.63 \pm 0.81^{*}$ \\
\hline & 20000 & 4944 & $1.03 \pm 0.14^{* *}$ & 3376 & $1.48 \pm 0.73^{*}$ \\
\hline \multirow{7}{*}{24 hours } & Control & & & & \\
\hline & 100 & 3516 & $8.08 \pm 0.68$ & 3033 & $8.08 \pm 0.70$ \\
\hline & 1250 & 3450 & $7.68 \pm 0.90$ & 4015 & $6.95 \pm 0.55$ \\
\hline & 2500 & 4322 & $6.94 \pm 0.77$ & 4115 & $6.32 \pm 0.86$ \\
\hline & 5000 & 4200 & $4.29 \pm 0.33 * *$ & 3321 & $4.67 \pm 0.33^{* *}$ \\
\hline & 10000 & 4023 & $3.11 \pm 0.38^{* *}$ & 3130 & $3.80 \pm 0.56^{* *}$ \\
\hline & 20000 & 3697 & $2.11 \pm 0.24 * *$ & 3900 & $3.08 \pm 0.41 * *$ \\
\hline
\end{tabular}

Note: $* \mathrm{P}<0.05, * * \mathrm{P}<0.001$ as compared to the untreated control plants. 


\subsection{Micronuclei Formation Rate of Vicia faba Root Tip Cells}

The water extract of $A$. cherimolia was able to induce micronuclei formation (Table 4). In plants treated with higher concentrations $(10000,20000 \mathrm{ppm})$ of $A$. cherimolia water extract, we observed more than one micronucleus per cell (Figure 2a) with the formation of nuclear bud (Figure 2b). Interestingly, no micronuclei were detected in the root cells of Vicia faba plants treated with all the used concentrations of $P$. americana either for 4 or 24 h (Table 4).

Table 4. Effect of plant extracts on micronucleus formation rate in Vicia faba root tip cells

\begin{tabular}{llll}
\hline \multirow{2}{*}{ Time } & \multirow{2}{*}{ Treatment } & \multicolumn{2}{l}{ Micronuclei formation rate (\%) } \\
\cline { 3 - 4 } & & Persea americana & Annona cherimolia \\
\hline \multirow{4}{*}{ 4 hours } & Control & --- & --- \\
& 100 & --- & 1.68 \\
& 1250 & --- & 1.86 \\
& 2500 & --- & 2.12 \\
& 5000 & --- & 2.83 \\
& 10000 & --- & 3.23 \\
& 20000 & --- & 3.40 \\
\hline \multirow{4}{*}{24 hours } & Control & --- & --- \\
& 100 & --- & 1.79 \\
& 1250 & --- & 1.93 \\
& 2500 & --- & 2.03 \\
5000 & --- & 2.45 \\
& 10000 & --- & 3.37 \\
20000 & --- & 3.80 \\
\hline
\end{tabular}

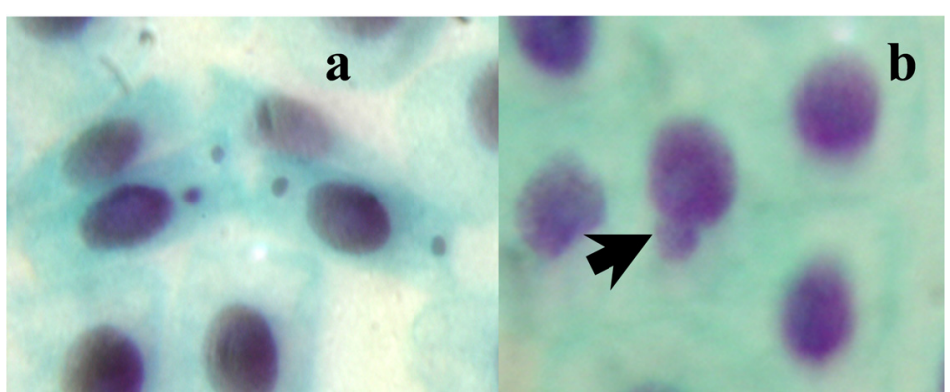

Figure 2. Effect of A. cherimolia water extract on micronuclei formation rate. Micronuclei were linearly increasing in a dose dependant manner (a) Two micronuclei per cells and (c) nuclear bud were observed at higher concnetrations

\subsection{Chromosome Aberration Rate of Vicia faba Root Tip Cells}

Root tip cells treated with the plant extract of $P$. americana exhibited the least chromosomal abnormalities as compared with the corresponding control. This result applies for both treatment duration used ( 4 or $24 \mathrm{~h})$. The most common abnormalities were stickiness (Figure 3a) in plants treated with the water extract of $P$. americana fruit at relatively high concentrations. On the other hand, Chromosome laggards (Figure 3b) and disturbed metaphase chromosomes (Figure 3c), in addition to stickiness, are the most common abnormalities detected in plants treated with the leaf water extract of $A$. cherimolia. 

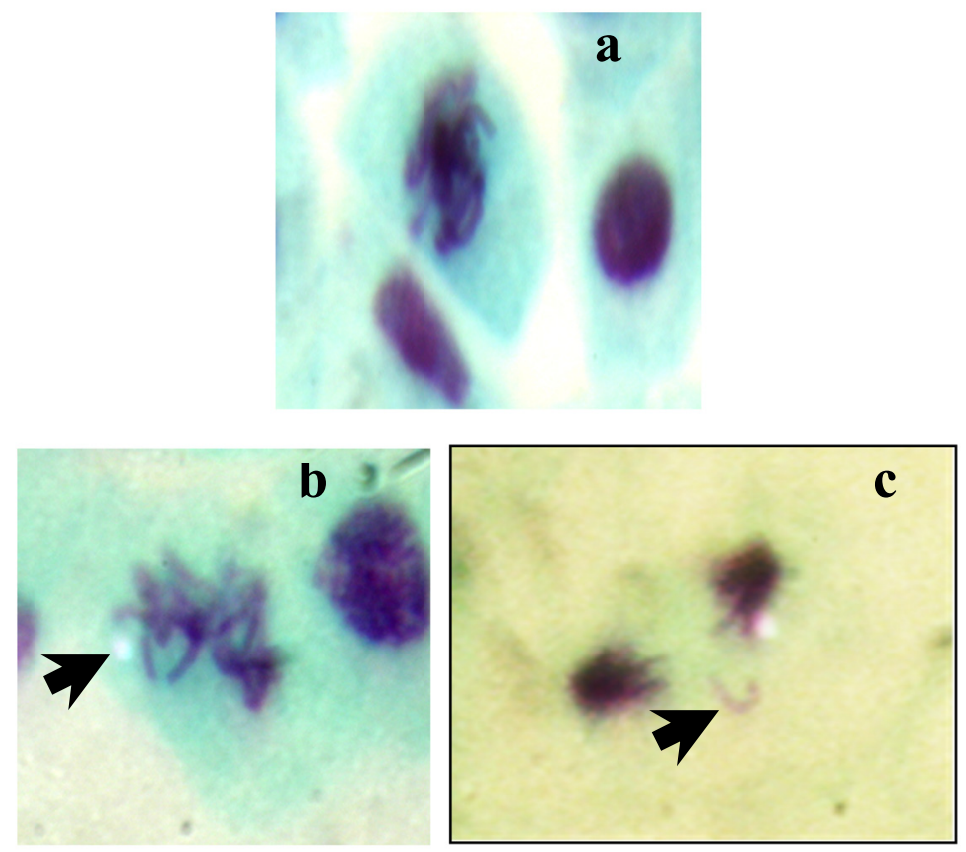

Figure 3. Chromsomal abnormalities induced upon treatments with the water extracts under study. Representative micrograph pictures showing the most common abnormalities. (a) Chromosomal stickiness is commonly observed in plants treated with the highest concentrations of $P$. americana and most of the concentrations of $A$. cherimolia (b) Disturbed metaphase and (c) chromosomal laggards were only observed in plants treated with the water extract of A. cherimolia leaves

\subsection{Percentage of Different Mitotic Phases}

As shown in Figure 4, the percentage of prophase cells were decreasing in a dose dependant manner in plants treated with $P$. americana or A. cherimolia water extracts for $4 \mathrm{~h}$. The same is true for $A$. cherimolia treated plants for $24 \mathrm{~h}$. On the other hand, the percentage of prophase cells was increasing linearly with the concentration applied in plants treated with P. americana for $24 \mathrm{~h}$ (Figure 4b). The metaphase and ana-telophase percentages were increasing as well in plants treated with CLWE for $24 \mathrm{~h}$, while they decreased in plants treated with AFWE for 24 h.

Table 5. The percentage of normal and abnormal mitosis in plant cells treated with the water extracts of P. americana and A. cherimolia at different concentrations

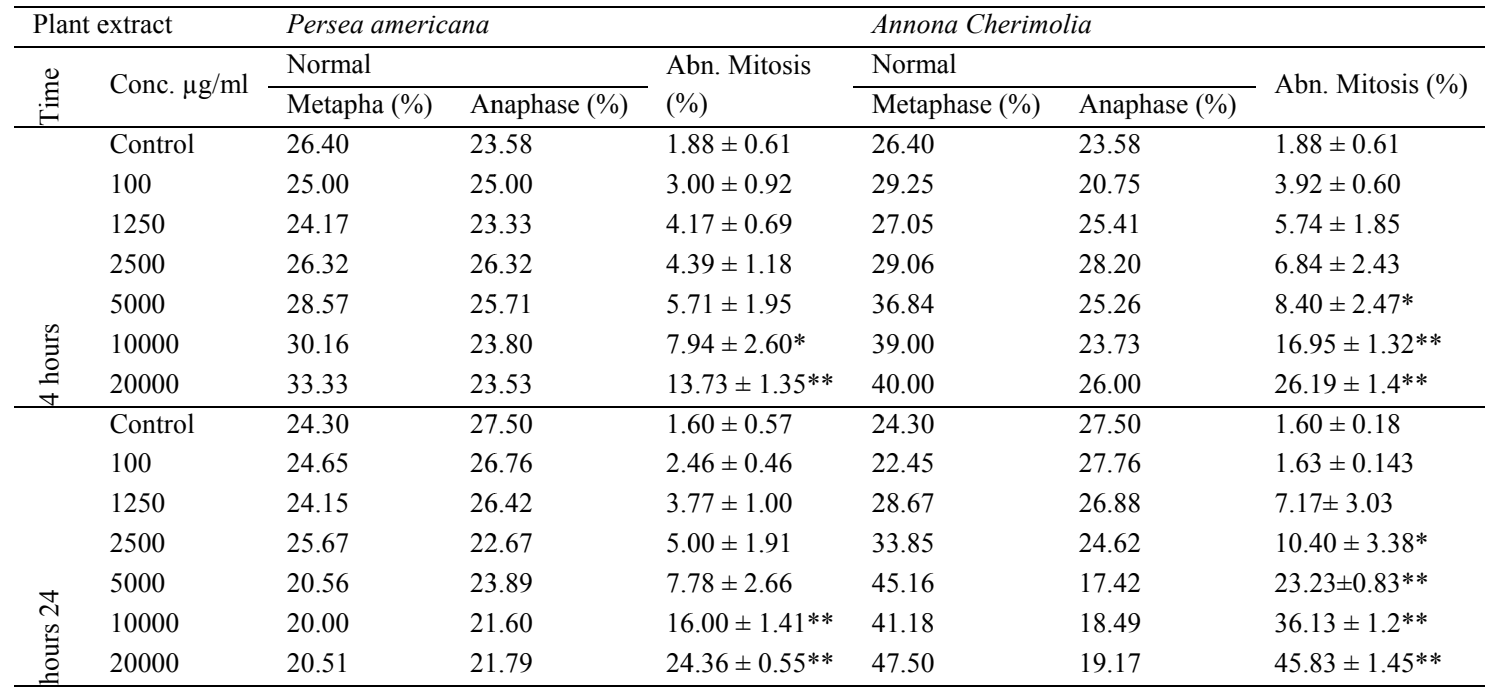




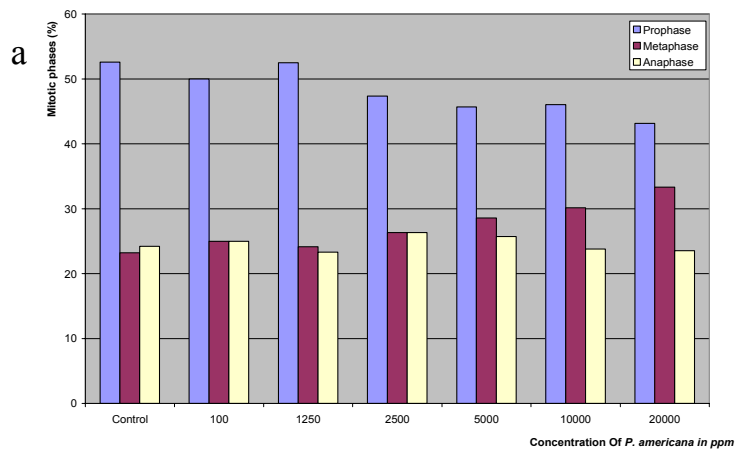

b
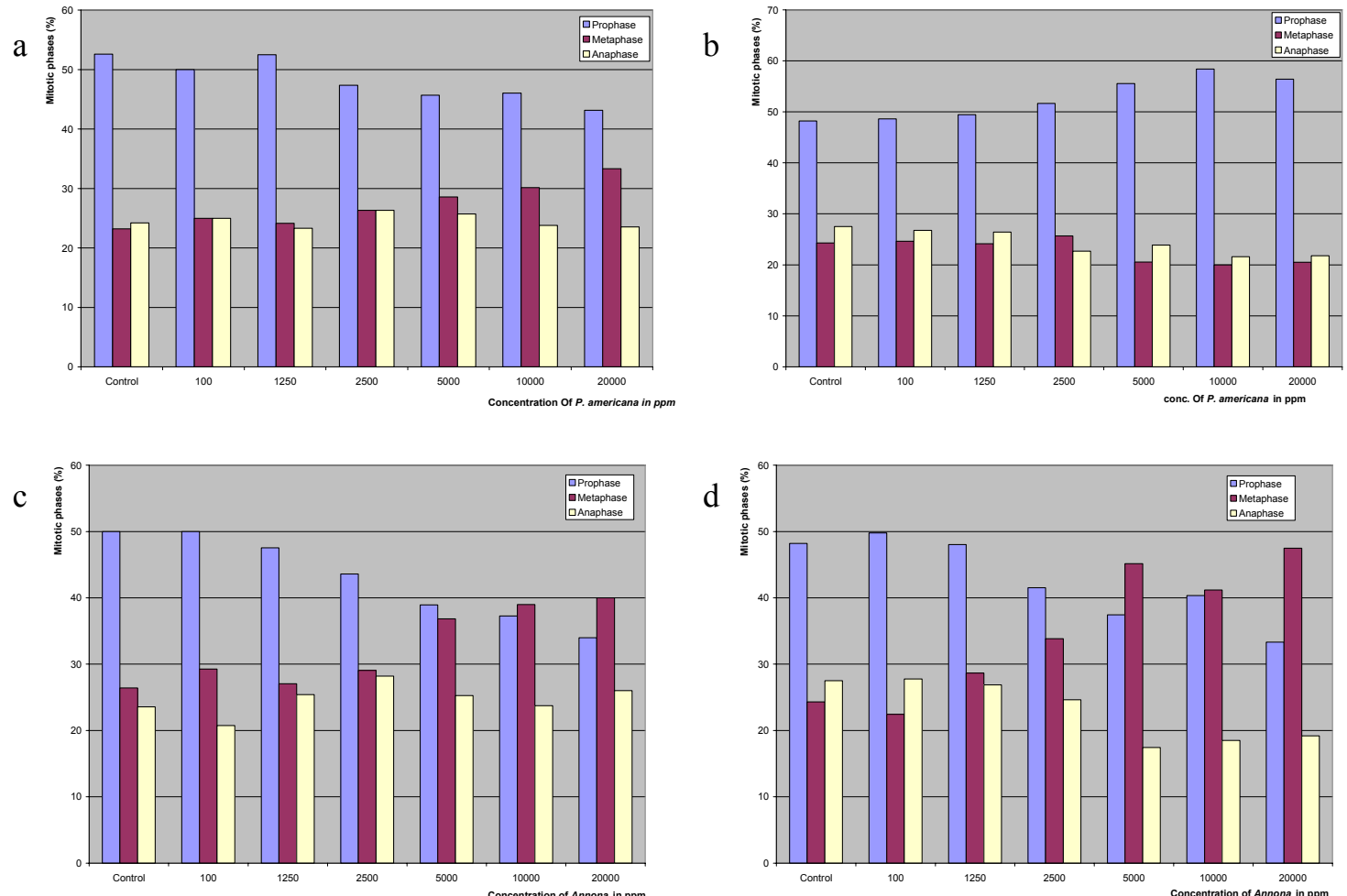

Figure 4. Mean values of different mitotic phases of treated and untreated $V$. faba root tip cells. Effect of water extract of $P$. americana (a): for 4 and (b): $24 \mathrm{~h}$. Effect of the water extract of $A$. cherimolia leaves (c): for 4 and (d): $24 \mathrm{~h}$

\section{Discussion}

Many studies, including our own, showed that phytochemicals extracted from Persea americana (avocado) and Annona cherimolia (cherimoya) can selectively induce cell cycle arrest, inhibit growth and enhance apoptosis in some cancer cell lines other than those used here (Ambrosio, Chunhua, Li, Kinghom, \& Ding, 2011; Ding, Chin, Kinghorn, \& D'Ambrosio, 2007; Garcia-Aguirre et al., 2008). For instance, in vitro studies had shown that the acetone extract of avocado fruit inhibited the growth of prostate cancer cells (Lu et al., 2005) while its chloroform extract inhibited the growth of oral cancer cells (Ding et al., 2009). Fractions from the ethanol extract of cherimoya inhibited the growth of human colon cancer and increased the micronuclei formation in mice erythrocytes (Garcia-Aguirre et al., 2008). However, the effect of avocado fruit water extract (AFWE) and cherimoya leaf water extract (ALWE) have not been reported before either on cancer or plant cells, as far as the authors are aware of. This prompted us to test the properties of AFWE and ALWE in order to mimic the natural way of their consumption by humans. This was carried out using two bio-screeing approaches: 1- cancer cell MTT and 2- Vicia faba root tip - bioassays.

In order to measure their cytotoxic properties, Four cancer cell lines [lung (A549), liver (HepG-2), colon (HT-29) and breast (MCF-7)] were incubated with $100 \mu \mathrm{g} / \mathrm{ml}$ of AFWE or CLWE for $48 \mathrm{~h}$. The Viability of cancer cells was measured using MTT assay. Both extracts resulted in more than $90 \%$ growth inhibition in all cancer cell lines as shown in Table 1. This indicates that AFWE and CLWE posses the ability to arrest the growth of cancer cells used in this study. To determine the concentration at which AFWE and ALWE can inhibit 50\% of cancer cell growth, we treated all cell lines with series of diluted concentrations and measured cell viability using MTT assay. $\mathrm{LC}_{50}$ values are shown in Table 2 for both extracts. Avocado and cherimoya water extract exhibited low $\mathrm{LC}_{50}=$ $13.3 \& 10 \mu \mathrm{g} / \mathrm{ml}$ in HepG-2 and $\mathrm{LC}_{50}=22 \& 16 \mu \mathrm{g} / \mathrm{ml}$ in HT-29 cell lines, respectively. Therefore, avocado and cherimoya represent very promising sources for anticancer drugs at least for liver and colon cancers. 
In the second approach, we used plant system to determine the effect of AFWE and CLWE on mitotic index (MI), micronuclei (MN) formation rate and chromosomal abnormalities. MI, MN and chromosomal abnormalities are well recognized markers to measure the mitodepressive and genotoxic properties of a test substance using plant cells. To date, there are no published data assessing the effect of avocado or cherimoya on Vicia faba root tip cells. Roots of Vicia faba plants were treated with 100, 1250, 2500,5000,10000, $20000 \mu \mathrm{g} / \mathrm{ml}$ of AFWE or ALWE for 4 and $24 \mathrm{~h}$. We have noticed a decrease in mitotic index values within root-tips treated with AFWE or ALWE, as compared with the untreated control (Table 3). This decrease was more pronounced in case of AFWE treatments (Table 3). This indicates that both extracts are mitodepressive. Mitodepressive effect had been assumed to result from the inhibition of cells access to mitosis (Badr \& Ibrahim, 1987) which is likely attained by preventing DNA biosynthesis or / and microtubule and chromatin organization (Yüzbaşığlu, Ãœnal, Sancak, \& Kasap, 2003). This will lead into a slower progression of cells from $\mathrm{S}$ (DNA synthesis) phase to M (mitosis) phase of the cell cycle (Blakemore, Boes, Cordell, \& Manson, 2013).

The percentages of different mitotic phases (Prophase, metaphase, and ana-telophase) were decreasing in a dose dependant manner in AFWE (4 h) and CLWE (4 and $24 \mathrm{~h}$ ) treated plants (Figures. 1-a, c \& d). When plants treated with AFWE for $24 \mathrm{~h}$, the prophase cell percentage was progressively increasing in a dose dependant manner (Figure 1b). Thus, it can be assumed that AFWE may have arrested cell division via interfering with DNA biosynthesis rather than affecting other stages in cell cycle.

The induction of micronuclei (MN) had been used in many studies as an indicator of genotoxicity (Cavas \& Ergene-Gozukara, 2005). In this work, the genotoxic effect of AFWE and CLWE was determined using the frequency of micronuclei (MN) formation. This will give us an idea about the safety of using these extracts in cancer therapies in future applications. We observed that the decrease in the mitotic index was associated with a significant increase in micronuclei (MN) formation rate in ALWE treated plants at all concentrations used (Table 4). We also observed the formation of two micronuclei per cell (Figure 2 a) and nuclear bud (Figure 2 b) at higher concentrations of CLWE (10000 and $20000 \mu \mathrm{g} / \mathrm{ml})$. Interestingly, no micronuclei were detected in plants treated with all concentrations of AFWE.

Chromosomal stickiness was the only abnormality observed at a significant level in AFWE treated plants. This gives an indication that the mitodepressive effect of avocado is more potent to an extent that it may had prohibited further cell division. On contrary, the clastogenic effect of cherimoya included chromosomal stickiness, bridges, laggards and disturbed metaphase. In this connection, the presence of micronuclei is commonly associated with structural and numerical chromosomal aberrations induced by clastogenic agents that cause chromosomal breaks and aneugenic agents that disturb microtubule (Bellini et al., 2006; Bellini et al., 2006; Benfenati et al., 2009; Dufour, Kumaravel, Nohynek, Kirkland, \& Toutain, 2006). This result suggests that both extracts interfered with the cell cycle. It can also be assumed that CLWE may be affecting chromatin and microtubule organization as indicated by micronuclei formation and chromosomal breaks. The mode of action of AFWE and CLWE as Mitodepressive agents needs further investigation.

\section{Conclusion}

This study highlighted the value of avocado fruit and cherimoya leaves to be used as promising sources for anticancer drugs. Both extracts showed potent cytotoxic activity toward cancer cells. However, avocado should be given more attention in this respect due to less chromosomal abnormalities associated with its treatment as compared to cherimoya.

This study can also be used to compare between the efficiency of MTT cancer cell viability and root tip assay in determining the cytotoxic properties of a plant extract toward cancer cells. Our results indicated that both bioassays can lead into the same conclusion. Thus, Vicia faba root tip assay can be used as an initial screening step particularly when large number of extracts is involved. The initial screening can then be followed by extra analysis for the promising extracts to determine the effective dose, selectivity, ...... etc using animal models and human cell lines. When it comes to plant bioassay, we found that reduction in mitotic index may indicate the cytotoxic effect of a plant extract on cancer cells. However, MN frequency and chromosomal abnormalities should be considered to validate the bio safety of the extract under investigation.

\section{References}

Abrahim, N. N., Kanthimathi, M. S., \& Abdul-Aziz, A. (2012). Piper betle shows antioxidant activities, inhibits MCF-7 cell proliferation and increases activities of catalase and superoxide dismutase. BMC Complement Altern Med, 12, 220-235. http://dx.doi.org/10.1186/1472-6882-12-220 
Adebajo, A. C., Ayoola, M. D., Odediran, S. A., Aladesanmi, A. J., Schmidt, T. J., \& Verspohl, E. J. (2012). Evaluation of ethnomedical claim iii(a): anti-hyperglycaemic activities of Gongronema latifolium root and stem. J. Diabetes.

Alali, F., Liu, X., \& McLaughlin, J. (1999). Cytotoxic annonaceous acetogenins from Annona muricata. J. Nat. Prod, 62, 504-540. http://dx.doi.org/10.1021/np980406d

Am, R., Al-Malki, A. L., Refai, M. Y., Kumosani, T. A., \& Moselhy, S. S. (2013). Phytochemical analysis of Convolvulus hystrix Vahl and its biological effects in rats. Toxicol Ind Health. Retrieved from http://www.ncbi.nlm.nih.gov/pubmed/23315089

Ambrosio, S., Chunhua, H., Li, P., Kinghom, D., \& Ding, H. (2011). Aliphatic acetogenin constituents of avocado fruits inhibit human oral cancer cell proliferation by targeting the EGFR/RAS/RAF/MEK/ERK1/2 pathway. Biochem Biophys Res Commun, 409(3), 465-469. http://dx.doi.org/10.1016/j.bbrc.2011.05.027

Badr, A., \& Ibrahim, A. G. (1987). Effect of herbicide Glean on mitosis, chromosomes and nücleic acids in Alium cepa and Vicia faba root meristems. Cytologia, 52, 293-302. http://dx.doi.org/10.1508/cytologia.52.293

Bayrami, G., \& Boskabady, M. H. (2013). The potential effect of the extract of Crocus sativus and safranal on the total and differential white blood cells of ovalbumin-sensitized guinea pigs. Res Pharm Sci, 7(4), 249-255.

Bellini, M. F., Angeli, J. P., Matuo, R., Terezan, A. P., Ribeiro, L. R., \& Mantovani, M. S. (2006). Antigenotoxicity of Agaricus blazei mushroom organic and aqueous extracts in chromosomal aberration and cytokinesis block micronucleus assays in CHO-k1 and HTC cells. Toxicol. In Vitro, 20(3), 355-360. http://dx.doi.org/10.1016/j.tiv.2005.08.009

Benfenati, E., Benigni, R., Demarini, D. M., Helma, C., Kirkland, D., Martin, T. M., ... Yang, C. (2009). Predictive models for carcinogenicity and mutagenicity: frameworks, state-of-the-art, and perspectives. J. Environ. Sci. Health. Part C, Environ. Carcinogen. Ecotoxicol. Rev., 27(2), 57-90. http://dx.doi.org/10.1080/10590500902885593

Benmebarek, A., Zerizer, S., Laggoune, S., \& Kabouche, Z. (2013). Immunostimulatory activity of Stachys mialhesi de Noe. Allergy Asthma Clinical Immunology, 9(1), 2. http://dx.doi.org/10.1186/1710-1492-9-2

Bhagat, M., Sharma, V., \& Saxena, A. K. (2012). Anti-proliferative effect of leaf extracts of Eucalyptus citriodora against human cancer cells in vitro and in vivo. Ind. J. Biochem. Biophy., 49(6), 451-457.

Blakemore, L. M., Boes, C., Cordell, R., \& Manson, M. M. (2013). Curcumin-induced mitotic arrest is characterized by spindle abnormalities, defects in chromosomal congression and DNA damage. Carcinogenesis, 34(2), 351-360. http://dx.doi.org/10.1093/carcin/bgs345

Buapool, D., Mongkol, N., Chantimal, J., Roytrakul, S., Srisook, E., \& Srisook, K. (2013). Molecular mechanism of anti-inflammatory activity of Pluchea indica leaves in macrophages RAW 264.7 and its action in animal models of inflammation. J Ethnopharmacol. http://dx.doi.org/10.1016/j.jep.2013.01.014

Cavas, T., \& Ergene-Gozukara, S. (2005). Genotoxicity evaluation of metronidazole using the piscine micronucleus test by acridine orange fluorescent staining. . Environ. Toxicol. and Pharmacol., 19, 107-111. http://dx.doi.org/10.1016/j.etap.2004.05.007

Chandra, P., Yadav, E., Mani, M., Ghosh, A. K., \& Sachan, N. (2013). Protective effect of Lygodium flexuosum (family: Lygodiaceae) against excision, incision and dead space wounds models in experimental rats. Toxicol Ind Health. http://dx.doi.org/10.1177/0748233712471704

Cotelle, S., Masfaraud, J.-F., \& Férard, J.-F. (1999). Assessment of the genotoxicity of contaminated soil with the Allium/Vicia micronucleus and the Tradescantia micronucleus assays. Mutat. Res., 426, $161-171$. http://dx.doi.org/10.1016/S0027-5107(99)00063-9

Darlington, C. D., \& La-Cour, C. L. (1976). The handling of chromosomes (3th ed.). New York, USA: Allen \& Unwin, 1960.

Ding, H., Chin, Y., Kinghorn, A., \& D'Ambrosio, S. (2007). Chemopreventive characteristics of avocado fruit. Semin Cancer Biol, 17(5), 386-394. http://dx.doi.org/10.1016/j.semcancer.2007.04.003

Ding, H., Han, C., Guo, D., Chin, Y., Ding, Y., Kinghorn, A., \& D'Ambrosio, S. (2009). Selective Induction of Apoptosis of Human Oral Cancer Cell Lines by Avocado Extracts Via a ROS-Mediated Mechanism. Nutrition and Cancer, 61(3), 348-356. http://dx.doi.org/10.1080/01635580802567158

Dong, Y., \& Zhang, J. (2010). Testing the genotoxicity of coking wastewater using Vicia faba and Hordeum vulgare bioassays. Ecotoxicol. and Environ. Safty, 73(5), 944-948. http://dx.doi.org/10.1016/j.ecoenv.2009.12.026

Dufour, E. K., Kumaravel, T., Nohynek, G. J., Kirkland, D., \& Toutain, H. (2006). Clastogenicity, photo-clastogenicity or pseudo-photo-clastogenicity: Genotoxic effects of zinc oxide in the dark, in pre-irradiated or simultaneously irradiated Chinese hamster ovary cells. Mut. Res., 607(2), 215-224. http://dx.doi.org/10.1016/j.mrgentox.2006.04.015 
El-Menshawi, B., Fayad, W., Mahmoud, K., El-Hallouty, S., El-Manawaty, M., Olofsson, M., \& Linder, S. (2010). Screening of natural products for therapeutic activity against solid tumors. Indian J Exp Biol., 48(3), $258-264$.

Garcia-Aguirre, K., Zepeda- Vallejo, L., Gallegos, E.-R., Alv arez-Gonzalez, I., \& Madrigal-Bujaidar, E. (2008). Genotoxic and Cytotoxic Effects Produced by Acetogenins Obtained from Annona cherimolia MILL Biol. Pharm. Bull., 31(12), 2346-2349. http://dx.doi.org/10.1248/bpb.31.2346

Haniadka, R., Popouri, S., Palatty, P. L., Arora, R., \& Baliga, M. S. (2013). Medicinal plants as antiemetics in the treatment of cancer: A review. Integ. Cancer Ther., 11(1), 18-28. http://dx.doi.org/10.1177/1534735411413266

Kawagishi, H., Fukumoto, Y., Hatakeyama, M., He, P., Arimoto, H., \& Matsuzawa, T. (2001). Liver injury suppressing compounds from avocado (Persea americana). J Agric Food Chem, 49, 2215-2221. http://dx.doi.org/10.1021/jf0015120

Konuk, M. B., Liman, R., \& CİĞERCI, H. (2007). Determination of genotoxic effect of Boron on Allium cepa root meristematic cells. Pakistan J. of Bot., 39(1), 73-79.

Lu, Q.-Y., Arteaga, J., Zhang, Q., Huerta, S., Go, L., \& Heberemail, D. (2005). Inhibition of prostate cancer cell growth by an avocado extract: role of lipid-soluble bioactive substances. The Journal of Nutritional Biochemistry, 16(1), 23-30. http://dx.doi.org/10.1016/j.jnutbio.2004.08.003

Ma, T. H., Cabrera, G. L., \& Owens, E. (2005). Genotoxic agents detected by plant bioassays. Reviews in Environmental Health, 20(1), 1-13. http://dx.doi.org/10.1515/REVEH.2005.20.1.1

Mosmann, T. (1983). Rapid colorimetric assay for cellular growth and survival: application to proliferation and cytotoxic assay. J. Immuno. Met., 65(55-63). http://dx.doi.org/10.1016/0022-1759(83)90303-4

Newman, D., \& Cragg, G. (2007). Plants as a source of anti-cancer agents. J Ethnopharmacol., 100, $72-79$.

Paul, R., Kulkarni, P., \& Ganesh, N. (2011). Avocado fruit (Persea americana Mill) exhibits chemo-protective potentiality against cyclophosphamide induced genotoxicity in human lymphocyte culture. J Exp Ther Oncol, 9(3), 221-230.

Qian, X. W. (2004). Study on teratogenic effect of potassium dichromate on Vicia faba root tip cells. J. zhejiang Univ. Sci. B, 26(3), 337-342.

Rates, S. (2001). Plants as source of drugs. Toxicon, 39, $603-613$. http://dx.doi.org/10.1016/S0041-0101(00)00154-9

Yüzbaşığlu, D., Ãœnal, F., Sancak, C., \& Kasap, R. (2003). Cytological effects of the herbicide racer "flurochloridone" on Allium cepar Caryologia, http://dx.doi.org/10.1080/00087114.2003.10589312

\section{Copyrights}

Copyright for this article is retained by the author(s), with first publication rights granted to the journal.

This is an open-access article distributed under the terms and conditions of the Creative Commons Attribution license (http://creativecommons.org/licenses/by/3.0/). 